\title{
Food Iron Absorption Measured by an Extrinsic Tag
}

\author{
J. D. Cook, M. LaYrisse, C. Martinez-Torres, R. Walker, \\ E. Monsen, and C. A. Finch \\ From the Departments of Medicine, Botany, and Home Economics, \\ University of Washington, Seattle, Washington 98195 and the \\ Instituto Venezolano de Investigaciones Cientificas, \\ Caracas, Venezuela
}

A B STRACT The paper describes the use of an extrinsic tag of inorganic radioiron to determine the total absorption of nonheme iron from a complete meal. The method was developed by measuring the iron absorbed from vegetable foods containing biosynthetically incorporated ${ }^{55} \mathrm{Fe}$ (intrinsic tag) and from ${ }^{58} \mathrm{Fe}$ added as a small dose of inorganic iron to the same meal (extrinsic tag). In studies with maize, black bean, and wheat, a consistent extrinsic: intrinsic radioiron absorption ratio averaging 1.10 was observed. Similar results were obtained with either ferrous or ferric iron as the extrinsic tag, and with doses of the latter ranging from 0.001 to $0.5 \mathrm{mg}$ iron added to a test meal containing $2-4 \mathrm{mg}$ of food iron. Adding the radioiron at different stages in preparation of the test meal also had little effect. Separate administration of the extrinsic tag was less satisfactory when small portions of a single food were employed, but with a complete meal, the separate dose was preferable. The extrinsic tag provided a valid measure of absorption despite marked differences in the iron status of the subject, and with wide changes in absorption imposed by adding desferrioxamine or ascorbic acid to the test meal. These findings indicate that there is a common pool of nonheme iron, the absorption of which is influenced by various blocking or enhancing substances present in the meal.

\section{INTRODUCTION}

The principle of employing biosynthetically tagged foods, described originally by Moore and Dubach (1) has been applied extensively in studies of iron availability from various plant and vegetable foods (2-13). Although these studies have yielded useful information, this kind of approach has serious limitations. Not only is the preparation of labeled foods difficult, but their absorp-

\footnotetext{
Received for publication 25 August 1971 and in revised form 29 November 1971.
}

tion differs depending upon whether the tagged food is eaten by itself or with other foods $(7,11,12)$. Thus, results obtained by biosynthetic labeling may have little bearing on the problem of iron absorption from a normal diet.

The objective of the present study was to measure the combined absorption of nonheme iron from all food sources in a regular meal. A comparison was made between the absorption of ${ }^{55} \mathrm{Fe}$ incorporated biosynthetically into the food by hydroponic culture (intrinsic tag) and a tracer dose of inorganic ${ }^{\circ} \mathrm{Fe}$ (extrinsic tag) administered in the same meal. The close and highly consistent relationship observed between the absorption of these two tags indicates the feasibility of assessing the absorption of nonheme iron in a normal diet by using an extrinsic label.

\section{METHODS}

Experimental subjects. Iron absorption was measured in 180 volunteer subjects from an agricultural area of Venezuela and from Seattle, Washington. Except for a high prevalence of iron deficiency, all of the subjects were otherwise healthy and free of disorders known to affect the absorption of iron. Measurements of packed cell volume, serum iron $(14)$, and iron-binding capacity $(15,16)$ were performed in all subjects. The results of these tests in the 96 females and 84 males are listed individually in Tables IV and V of the Appendix and summarized in Table I.

Radioiron absorption measurements. The test meal tagged with ${ }^{56} \mathrm{Fe}$ and ${ }^{50} \mathrm{Fe}$ was eaten in the morning by subjects who had fasted overnight and were allowed no further food or drink for $3 \mathrm{hr}$. The amount of radioactivity in the food administered was determined by counting three weighed samples and extrapolating these counts to the weight of the total test meal. 2 wk later, radioiron absorption from this meal was calculated from the ${ }^{50} \mathrm{Fe}$ and ${ }^{55} \mathrm{Fe}$ activity in the subjects' blood, using an estimated total blood volume based on sex, height, and weight (17). Red cell incorporation of absorbed radioiron was assumed to be $90 \%$ in all subjects.

Immediately after this study, the subjects were again fasted and then given orally $3 \mathrm{mg}$ iron as ${ }^{59} \mathrm{FeSO}_{4}$ and ascorbic acid ( 2 moles ascorbate per mole of iron) to provide 
TABLE- I

Iron Status of Composite Group of 169 Volunteer Subjects

\begin{tabular}{lcc}
\hline & Median & 10-90 Percentile \\
\hline Age, $y r$ & 33.0 & $16-55$ \\
Hematocrit, \% & 40.0 & $35.2-45.5$ \\
Serum iron, $\mu \mathrm{g} / 100 \mathrm{ml}$ & 80.0 & $29-133$ \\
Transferrin saturation, \% & 24.0 & $7.2-40.6$ \\
Inorganic iron absorption*, \% & 35.1 & $6.0-80.6$ \\
\hline
\end{tabular}

* Reference dose of $3 \mathrm{mg}$ ferrous ascorbate.

a reference dose. Absorption of this iron was determined in blood obtained 2 wk later from the rise in ${ }^{50} \mathrm{Fe}$ activity over the previous level.

Double isotope counting of ${ }^{55} \mathrm{Fe}$ and ${ }^{50} \mathrm{Fe}$ was performed either by liquid scintillation counting as described by Eakins and Brown (18) or Dern and Hart $(19,20)$, or by the separate assay of ${ }^{50} \mathrm{Fe}$ activity with a 3 -inch $\mathrm{NaI}$ well-type scintillation counter and ${ }^{56} \mathrm{Fe}$ activity with a proportional counter recently designed for direct measurement of blood ${ }^{55} \mathrm{Fe}$ activity (21). Sufficient counts were obtained on duplicate samples to reduce the net counting rate error to less than $\pm 2 \%$ in subjects absorbing more than $1 \%$ of the test dose.

Preparation of labeled foods. The preparation of biosynthetically tagged corn, wheat, soybean, and black bean was performed by adding ${ }^{55} \mathrm{Fe}$ to hydroponic culture media as previously described $(5,10)$. The harvested foods contained between 25 and $120 \mu \mathrm{g} \mathrm{Fe} / \mathrm{g}$ of dry food and ranged in SA from 45 to $90 \mu \mathrm{Ci} / \mathrm{mg} \mathrm{Fe}$. Labeled food was mixed with two to four times its weight of unlabeled carrier food to obtain test meals containing $10 \mu \mathrm{Ci}{ }^{55} \mathrm{Fe}$ and either $2 \mathrm{mg}$ elemental iron (maize and wheat) or $3 \mathrm{mg}$ elemental iron (soybean and black bean).

The extrinsic tag was prepared by mixing $5 \mu \mathrm{Ci}{ }^{50} \mathrm{Fe} \mathrm{Cl}_{3}$ (SA, $10-15 \mathrm{mCi} / \mathrm{mg}$ ) with varying amounts of carrier $\mathrm{FeCl}_{\mathbf{3}}$. The dose of the extrinsic tag was usually $0.1 \mathrm{mg}$ iron with the exceptions noted later. The time of its administration in relation to the test meal was varied as part of the experimental design, as indicated in the appropriate sections.

Maize was prepared by boiling finely ground radioactive corn to obtain a gruel. Carrier maize was boiled separately and then ground to prepare a dough. The extrinsic tag solution was either added to the water used to boil the radioactive maize or was thoroughly homogenized with the radioactive gruel after boiling. The radioactive and carrier maize preparations were then thoroughly homogenized and divided into carefully weighed individual portions of approximately $100 \mathrm{~g}$ which were placed in aluminum pans and baked before administration.

Labeled black beans were boiled together with carrier beans in five to six times their weight of water in aluminum pots. The swollen beans were then mashed, mixed with the extrinsic tag solution, and cooked further before dispensing. Soybean meals were prepared as described previously (10); in this case, the extrinsic tag was taken separately in a small volume of water at the conclusion of the meal. Wheat was prepared as previously described (5), and the extrinsic tag was incorporated by adding it to the water used for making the wheat dough. Veal muscle was made into meat patties for ingestion with a test meal of labeled maize.

The validity of using an extrinsic tag to measure nonheme iron absorption from a complete meal was tested with a 700 cal standard meal of potatoes, beef, bread, margarine, peaches, milk, and hydroponically-labeled ${ }^{55} \mathrm{Fe}$ maize (Table II). This meal, estimated to have $4.5 \mathrm{mg}$ elemental iron from food composition tables (22), was found to contain $4.0 \mathrm{mg}$ by actual measurement. The extrinsic tag was incorporated in two ways. In the first, $0.1 \mathrm{mg}$ iron as $\mathrm{FeCl}_{3}$ was thoroughly mixed with the boiled maize, which was later homogenized in a Waring blendor with the remaining foods of the meal. In the alternate method, the extrinsic tag was administered separately at the end of the meal. These two methods of extrinsic tagging were tested in alternate subjects.

Statistical analysis. Food iron absorption was expressed in relation to the absorption of a standard reference dose of ferrous ascorbate in each subject. This method of expression provides an adjustment for differences in absorption due to individual variations in iron balance (10). Because of the skewed distribution of iron absorption data, the mean and standard deviation of the ratio between food iron and ferrous ascorbate absorption (absorption index) were calculated on the logarithmic scale and retransformed as antilogarithms to recover the original units (10).

The relationship between extrinsic and intrinsic radioiron absorption from the same meal (the $E$ : I ratio) was first analyzed by least squares regression. As shown in Fig. 1, the results were consistent with a regression line fitted through the origin. The variability about the regression line with simultaneous absorption measurements was constant at increasing levels of per cent absorption. Thus, the E: I ratio could be calculated from the slope of a least squares regression line fitted through the origin (reference 23, p. 166). The standard error of the estimate was used to compare the variability of the ratios in different studies using Bartlett's test (reference 23, p. 296). In studies with homogeneous variances, differences in the $\mathrm{E}: \mathrm{I}$ ratio were tested by covariance analysis (24).

\section{RESULTS}

Preliminary studies dealt with the valence of the iron employed as an extrinsic tag. In 18 studies on 6 subjects in which $\mathrm{FeSO}_{4}$ was added to maize, the mean absorption index for the extrinsic tag (geometric mean ratio of extrinsic tag to reference dose absorption) was 0.19 . In 15 studies on 5 subjects in which $\mathrm{FeCl}_{3}$ was used,

TABLE II

Composition of Meal Used to Evaluate Extrinsic Tag

\begin{tabular}{lcccc}
\hline \multicolumn{1}{c}{ Food item } & Weight & $\begin{array}{c}\text { Food } \\
\text { energy }\end{array}$ & Protein & Iron \\
\hline & \multicolumn{1}{c}{$g$} & $c a l$ & $\mathrm{~g}$ & $\mathrm{mg}$ \\
& 110 & 36 & 0.9 & 0.2 \\
Instant potatoes & 110 & 36 & 0.7 & 0.2 \\
Lean beef & 100 & 180 & 20.7 & 3.1 \\
Bread & 23 & 62 & 2.0 & 0.6 \\
Margarine & 20 & 144 & 0.1 & 0.0 \\
Peaches & 120 & 94 & 0.5 & 0.3 \\
Ice milk & 100 & 152 & 4.8 & 0.1 \\
Total & 583 & 704 & 29.7 & $4.5^{*}$ \\
\hline
\end{tabular}

* The meal contained $4.0 \mathrm{mg}$ iron by actual measurement. 
the mean absorption index was 0.22 . Trivalent iron was used in subsequent studies.

The effect of varying the dose of extrinsic tag was examined over a range from less than $0.001-0.5 \mathrm{mg} \mathrm{Fe}$ as $\mathrm{FeCl}_{3}$ added to the labeled maize. The results obtained in three groups of subjects (studies 1,2, and 3) are listed individually in Table IV of the Appendix and summarized in Table III. The mean E:I ratio in the three studies varied from 0.97 to 1.10 with an over-all mean of 1.06. An intermediate dose of $0.1 \mathrm{mg} \mathrm{Fe}$ as $\mathrm{FeCl}_{3}$ was chosen for extrinsic labeling in subsequent studies.

The effect of varying the manner of adding the extrinsic tag was next examined (Table III). With test meals of maize, $\mathrm{Fe}$ as $\mathrm{FeCl}_{3}$ was added before boiling in amounts of $0.001 \mathrm{mg}$ (study 4) and $0.1 \mathrm{mg}$ (study 5). In both instances, the mean $\mathrm{E}: \mathrm{I}$ ratio was 1.12 . When the iron was given separately, the ratios obtained were 1.43 with maize (study 6) and 1.27 with soybean (study $7)$. However, the variability of the ratio in individual subjects (SE of the estimate, 2.99 and 2.19) was greatly increased by this method of iron administration.

Absorption of the extrinsic tag was also examined with hydroponically labeled wheat (study 8) and black bean (study 9) by adding $0.1 \mathrm{mg} \mathrm{Fe}$ as $\mathrm{FeCl}_{3}$ to boiled food before baking. The mean $\mathrm{E}$ : I ratio was 1.18 with wheat and 0.99 with black bean as compared with 1.06 obtained with similarly tagged maize. These differences are not statistically significant.

In studies described so far, the mean absorption of food iron (intrinsic tag) in the various groups fell within the relatively narrow range of $1.5-6.3 \%$, with individual subjects showing variations from 0.1 to $24.4 \%$. To examine the validity of using an extrinsic tag at extremes in food iron absorption, test doses of maize were mixed with $500 \mathrm{mg}$ of either desferrioxamine $^{1}$ or ascorbic acid before administration (studies 10 and 11). Mean absorption of intrinsic tag was depressed to $0.6 \%$ with desferrioxamine, and increased to $22.0 \%$ with ascorbic acid. Nevertheless, the mean E:I ratios remained similar to those obtained previously, being 1.14 and 1.01 respectively.

The validity of the extrinsic tag for test meals containing more than a single food was then examined. The addition of veal muscle caused an increase in mean absorption of maize iron (intrinsic tag) to $9.7 \%$. Nevertheless, the $\mathrm{E}: \mathrm{I}$ ratio of 1.16 was similar to that obtained with maize alone. In the final two studies, iron absorbed from the 700 cal complete meal was measured. When extrinsic tag was given after the test meal prepared in the normal manner (study 13), the E: I ratio was 1.28 . With earlier addition of the extrinsic tag and complete homogenization of the meal (study 14), the ratio was

\footnotetext{
${ }^{1}$ Desferal, Ciba Pharmaceutical Co., Summit, N. J.
}

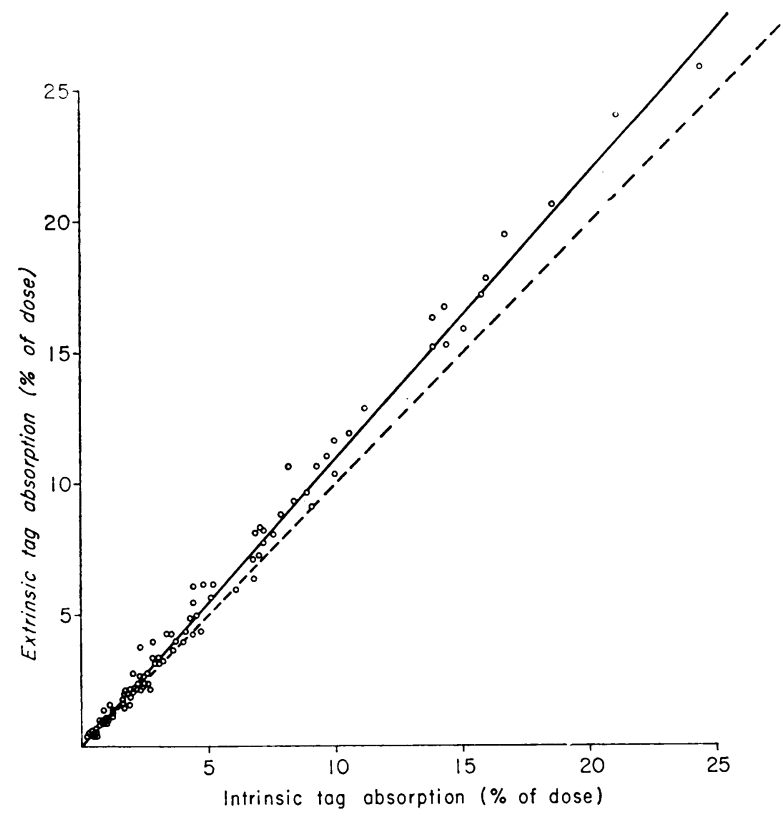

Figure 1 Food iron absorption from test meals tagged simultaneously with intrinsic and extrinsic radioiron. Included are all studies performed with an extrinsic tag of $0.1 \mathrm{mg}$ iron or less added to a normal test meal before administration (studies 1, 2, 4, 5, 8, 9, 12, and 14 listed in Table III). The mean ratio between absorption of extrinsic and intrinsic radioiron for the composite data is 1.10 (95\% confidence limits 1.09-1.10) calculated as the slope of the least squares regression line fitted through the origin and represented by the solid line. The interrupted line represents a $1: 1$ ratio.

1.06. Thus, the presence of several foods in a meal appeared to have little or no effect on the $E$ : I ratio as compared with giving a single food (study 2).

To permit statistical comparison of the E: I ratio calculated for the various studies listed in Table III, it was necessary that the results have similar variability in the ratio estimate. After excluding studies 6, 7, and 11 which had the highest, and study 9, the lowest values for the SE of the estimate, homogeneous variance was established with the remaining 10 studies. It could then be shown that the ratio of 1.28 observed with separate administration of the extrinsic tag to a complete meal (study 14) was significantly higher, and the ratio of 0.97 observed with an extrinsic dose of $0.5 \mathrm{mg} \mathrm{Fe}$ as $\mathrm{FeCl}_{3}$ added to maize (study 3) was significantly lower than the group as a whole. The ratio among the remaining eight studies are plotted in Fig. 1. They showed no statistical differences when tested by covariance analysis $(F=1.59$, $7 / 82$ degrees of freedom, $P>0.10$ ).

\section{DISCUSSION}

The daily turnover of iron in normal human subjects is small, amounting to only about $0.9 \mathrm{mg}$ in adult men 
TABLE III

Comparison of Intrinsic and

\begin{tabular}{|c|c|c|c|c|c|c|c|}
\hline \multirow[b]{2}{*}{ Study } & \multirow[b]{2}{*}{ Test meal } & \multicolumn{2}{|c|}{ Extrinsic tag } & \multirow{2}{*}{$\begin{array}{l}\text { No. of } \\
\text { Subjects }\end{array}$} & \multirow[b]{2}{*}{ Ageł } & \multirow[b]{2}{*}{ Hematocrit } & \multirow{2}{*}{$\begin{array}{l}\text { Tsf.t } \\
\text { sat.8 }\end{array}$} \\
\hline & & Dose & Method* & & & & \\
\hline & & $m g F e$ & & & $y r$ & $\%$ & $\%$ \\
\hline 1 & Maize & 0.001 & Mixed A & 13 & $30 \pm 4$ & $40 \pm 1$ & $23 \pm 3$ \\
\hline 2 & Maize & 0.1 & Mixed A & 18 & $30 \pm 2$ & $40 \pm 1$ & $26 \pm 3$ \\
\hline 3 & Maize & 0.5 & Mixed A & 12 & $36 \pm 4$ & $38 \pm 2$ & $15 \pm 3$ \\
\hline 4 & Maize & 0.001 & Mixed B & 12 & $31 \pm 5$ & $40 \pm 1$ & $26 \pm 3$ \\
\hline 5 & Maize & 0.1 & Mixed B & 15 & $33 \pm 3$ & $40 \pm 1$ & $21 \pm 3$ \\
\hline 6 & Maize & 0.1 & Separate & 11 & $33 \pm 5$ & $43 \pm 1$ & $31 \pm 3$ \\
\hline 7 & Soybean & 0.1 & Separate & 11 & $31 \pm 6$ & $42 \pm 1$ & $25 \pm 4$ \\
\hline 8 & Wheat & 0.1 & Mixed A & 13 & $41 \pm 4$ & $38 \pm 1$ & $23 \pm 3$ \\
\hline 9 & Black bean & 0.1 & Mixed A & 8 & $33 \pm 7$ & $41 \pm 1$ & $28 \pm 4$ \\
\hline 10 & $\begin{array}{c}\text { Maize plus } 500 \mathrm{mg} \\
\text { desferrioxamine }\end{array}$ & 0.1 & Mixed A & 12 & $41 \pm 2$ & $41 \pm 1$ & $23 \pm 2$ \\
\hline 11 & $\begin{array}{l}\text { Maize plus } 500 \mathrm{mg} \\
\text { ascorbic acid }\end{array}$ & 0.1 & Mixed A & 14 & $41 \pm 4$ & $40 \pm 1$ & $23 \pm 4$ \\
\hline 12 & Maize plus veal & 0.1 & Mixed A & 8 & $45 \pm 5$ & $39 \pm 2$ & $19 \pm 4$ \\
\hline 13 & $\begin{array}{l}\text { Maize with } \\
\text { complete meal }\end{array}$ & 0.1 & Separate & 11 & $22 \pm 1$ & $41 \pm 1$ & $34 \pm 4$ \\
\hline 14 & $\begin{array}{l}\text { Maize with } \\
\text { complete meal }\end{array}$ & 0.1 & Mixed A & 11 & $22 \pm 1$ & $41 \pm 1$ & $34 \pm 4$ \\
\hline
\end{tabular}

* In methods A and B, the extrinsic tag was added to the intrinsically labeled food, after and before boiling, respectively.

$\ddagger$ Mean \pm SEM.

$\|$ Geometric mean. Values in parenthesis represent \pm 1 sEM calculated on the logarithmic scale and retransformed as antilogarithms.

$\S$ Transferrin saturation.

I Slope $\pm \mathrm{SE}$ of the slope for a least squares regression line fitted through the origin.

${ }^{* *} \mathrm{SE}$ of the estimate.

(25). The absorptive process plays a key regulatory role, but current methods for measuring food iron absorption are unsatisfactory. Chemical balance studies lack the sensitivity required to measure the small quantity of iron absorbed from the normal diet. Biosynthetic labeling provides accurate measurements of iron availability from individual foods but not from a mixture of foods. The present study was undertaken to determine whether adding an extrinsic tag of inorganic radioiron to a normal meal might provide a reasonable measure of nonheme iron absorption.
There is some evidence in the literature to suggest that an extrinsic tag might be suitable. Sharpe, Peacock, Cooke, and Harris (26) found that marked inhibition of absorption occurs when food is added to a test dose of inorganic radioiron, and suggested that the degree of inhibition is related to the bulk of food added. The addition of an extrinsic tag to a standard meal was later proposed by Pirzio-Biroli and coworkers (27) as a practical approach to studying clinical abnormalities in the absorption of food iron. While the standard meal technique has since been widely applied for this pur- 


\begin{tabular}{|c|c|c|c|c|c|c|}
\hline \multirow{2}{*}{\multicolumn{3}{|c|}{ Iron absorption }} & \multicolumn{4}{|c|}{ Absorption ratios } \\
\hline & & & \multirow{2}{*}{$\frac{\text { Intrinsic\| }}{\text { Reference }}$} & \multirow{2}{*}{$\frac{\text { Extrinsic\| }}{\text { Reference }}$} & \multicolumn{2}{|c|}{ Extrinsic/Intrinsic } \\
\hline Intrinsic\| & Extrinsic\| & Reference\| & & & $b+S_{b} \mathbb{I}$ & SEE** \\
\hline & $\%$ of dose & & & & & \\
\hline $\begin{array}{c}2.7 \\
(19-3.8)\end{array}$ & $\begin{array}{c}3.1 \\
(22-4.3)\end{array}$ & $\begin{array}{c}29.8 \\
(23.9-37.2)\end{array}$ & $\begin{array}{c}0.09 \\
(0.06-0.13)\end{array}$ & $\begin{array}{c}0.10 \\
(0.08-0.14)\end{array}$ & $1.10 \pm 0.01$ & 0.29 \\
\hline $\begin{array}{c}4.8 \\
(3.9-5.8)\end{array}$ & 5.0 & $\begin{array}{c}48.7 \\
(43.3-5466\end{array}$ & $\begin{array}{c}0.10 \\
08-0.12)\end{array}$ & $\begin{array}{c}0.10 \\
(0.09-0.12)\end{array}$ & $1.06 \pm 0.01$ & 0.39 \\
\hline 3.9 & $\begin{array}{c}(4.1-0.1) \\
3.8\end{array}$ & $\begin{array}{c}40.0-34.0) \\
49.1\end{array}$ & 0.08 & 0.08 & $0.97 \pm 0.02$ & 0.30 \\
\hline$(3.3-4.6)$ & $(3.2-4.5)$ & $(41.5-58.3)$ & $(0.07-0.09)$ & $(0.07-0.09)$ & & \\
\hline $\begin{array}{c}1.6 \\
(1.2-2.3)\end{array}$ & $\begin{array}{c}2.0 \\
(1.5-2.7)\end{array}$ & $\begin{array}{c}30.0 \\
(23.6-38.2)\end{array}$ & $\begin{array}{c}0.05 \\
(0.04-0.07)\end{array}$ & $\begin{array}{c}0.07 \\
(0.05-0.08)\end{array}$ & $1.12 \pm 0.03$ & 0.42 \\
\hline $\begin{array}{c}4.0 \\
(3.6-5.2)\end{array}$ & $\begin{array}{c}4.6 \\
(3.6-5.9)\end{array}$ & $\begin{array}{c}45.2 \\
(36.3-56.2)\end{array}$ & $\begin{array}{c}0.09 \\
(0.07-0.11)\end{array}$ & $\begin{array}{c}0.10 \\
(0.08-0.13)\end{array}$ & $1.12 \pm 0.01$ & 0.35 \\
\hline $\begin{array}{c}2.6 \\
(1.6-4.2)\end{array}$ & $\begin{array}{c}3.8 \\
(2.3-6.3)\end{array}$ & $\begin{array}{c}18.5 \\
(13.6-25.1)\end{array}$ & $\begin{array}{c}0.14 \\
(0.09-0.23)\end{array}$ & $\begin{array}{c}0.21 \\
(0.13-0.34)\end{array}$ & $1.43 \pm 0.12$ & 2.99 \\
\hline $\begin{array}{c}6.3 \\
(4.3-9.1)\end{array}$ & $\begin{array}{c}7.8 \\
(5.4-11.3)\end{array}$ & $\begin{array}{c}42.2 \\
(30.6-58.2)\end{array}$ & $\begin{array}{c}0.15 \\
(0.10-0.22)\end{array}$ & $\begin{array}{c}0.19 \\
(0.13-0.26)\end{array}$ & $1.27 \pm 0.06$ & 2.19 \\
\hline $\begin{array}{c}2.6 \\
(2.0-3.4)\end{array}$ & $\begin{array}{c}3.0 \\
(2.3-4.0)\end{array}$ & $\begin{array}{c}21.6 \\
(18.1-25.9)\end{array}$ & $\begin{array}{c}0.12 \\
(0.09-0.16)\end{array}$ & $\begin{array}{c}0.14 \\
(0.11-0.18)\end{array}$ & $1.18 \pm 0.02$ & 0.49 \\
\hline $\begin{array}{c}1.5 \\
(1.2-2.0)\end{array}$ & $\begin{array}{c}1.2 \\
(0.8-1.7)\end{array}$ & $\begin{array}{c}25.5 \\
(23.0-28.2)\end{array}$ & $\begin{array}{c}0.06 \\
(0.05-0.07)\end{array}$ & $\begin{array}{c}0.06 \\
(0.03-0.07)\end{array}$ & $0.99 \pm 0.05$ & 0.26 \\
\hline $\begin{array}{c}0.6 \\
(0.5-0.7)\end{array}$ & $\begin{array}{c}0.7 \\
(0.6-0.8)\end{array}$ & $\begin{array}{c}40.7 \\
(35.5-46.7)\end{array}$ & $\begin{array}{c}0.01 \\
(0.01-0.02)\end{array}$ & $\begin{array}{c}0.02 \\
(0.01-0.02)\end{array}$ & $1.14 \pm 0.04$ & 0.12 \\
\hline $\begin{array}{c}22.0 \\
(16.9-28.5)\end{array}$ & $\begin{array}{c}22.5 \\
(17.3-29.2)\end{array}$ & $\begin{array}{c}36.5 \\
(30.1-44.2)\end{array}$ & $\begin{array}{c}0.60 \\
(0.52-0.70)\end{array}$ & $\begin{array}{c}0.62 \\
(0.53-0.71)\end{array}$ & $1.01 \pm 0.01$ & 1.12 \\
\hline $\begin{array}{c}9.7 \\
(7.5-12.5)\end{array}$ & $\begin{array}{c}11.6 \\
(9.2-14.6)\end{array}$ & $\begin{array}{c}47.0 \\
(40.4-54.5)\end{array}$ & $\begin{array}{c}0.21 \\
(0.16-0.26)\end{array}$ & $\begin{array}{c}0.25 \\
(0.20-0.31)\end{array}$ & $1.16 \pm 0.01$ & 0.45 \\
\hline $\begin{array}{c}5.6 \\
(4.4-7.1)\end{array}$ & $\begin{array}{c}7.2 \\
(5.7-9.3)\end{array}$ & - & - & - & $1.28 \pm 0.02$ & 0.70 \\
\hline $\begin{array}{c}3.4 \\
(2.5-4.7)\end{array}$ & $\begin{array}{c}4.0 \\
(2.9-5.3)\end{array}$ & - & - & - & $1.06 \pm 0.02$ & 0.61 \\
\hline
\end{tabular}

pose (26-33), any implication that the results provide a valid measure of iron absorption from the meal has been carefully avoided.

Schulz and Smith (4) compared the absorption of intrinsic and extrinsic iron, reporting a mean absorption of $9.1 \%$ in 10 children given milk labeled in vivo as compared with the mean of $10.6 \%$ in 10 children given a test dose of milk to which radioiron had been added. In a similar study with a test meal of eggs, a mean absorption of 11 and $12 \%$ with intrinsic and extrinsic tagging was reported in five and three children, re- spectively. These studies did show a general agreement in the two labeling methods, but they did not supply sufficient data to permit firm conclusions about the general validity of the extrinsic tag method.

In the present study, dual isotope measurements of absorption from a single test dose of food labeled intrinsically with ${ }^{55} \mathrm{Fe}$ and extrinsically with ${ }^{\infty} \mathrm{Fe}$, have provided precise estimates of the relative absorption of the two labels. For example, correlation coefficients between log percentage absorption of intrinsic and extrinsic radioiron given in the same test meals were greater 
than 0.99 in all but two of the studies listed in Table III (exceptions were studies 6 and 7 in which the extrinsic tag was not mixed with the test meal of single food). The close correlation is also reflected in the SE of the ratio estimate which was less than $\pm 5 \%$. While the $10 \%$ greater absorption of the extrinsic tag was statistically significant, this magnitude of error is of little concern in the evaluation of food iron absorption, and appropriate adjustments can be made if necessary.

Several methods of adding the extrinsic tag to the test meal yielded similar results. Thus, no differences were observed between ferrous and ferric salt; nor did varying the dose of the extrinsic tag from 0.001 to 0.1 $\mathrm{mg}$ iron have any measurable effect. The finding of a slightly lower ratio of 0.97 when the extrinsic tag dose was $0.5 \mathrm{mg} \mathrm{Fe}$ is in keeping with other studies of food iron supplementation in which a ratio close to unity was obtained with much larger doses of extrinsic tag. ${ }^{2}$

Administering the extrinsic tag separately from the test meal of a single food causes a significantly greater variation in the $E: I$ ratio among the individual subjects. This effect was presumably due to incomplete mixing of the tag with the smaller amount of food, because separate administration of the tag with a complete meal gave a variability in the $E: I$ ratio no greater than when the ${ }^{50} \mathrm{Fe}$ was mixed with the food. With smaller test meals, as well as with the complete meal, separate administration of the extrinsic tag was associated with a significantly higher E:I ratio of approximately 1.3. However, in studies with a complete meal, it appears preferable to accept this higher ratio associated with separate administration of the extrinsic tag rather than to homogenize the meal, because the reduced palatability of the homogenized meal may in itself have an adverse effect. This is suggested by the significantly reduced absorption of intrinsic radioiron from homogenized (study 13) vs. unhomogenized (study 14) food. The subjects in this study were able to ingest the homogenized meal only after it had been partially frozen.

A theoretical objection to extrinsic tagging was raised by Moore after a careful review of data obtained by biosynthetic tagging and with the standard meal technique (34). Although in normal subjects the two methods gave comparable results, in iron-deficient subjects the mean absorption of $43.4 \%$ in 38 subjects given a standard meal was appreciably higher than the mean of $18.9 \%$ in 48 patients given biosynthetically labeled foods. This suggestion that an extrinsic tag cannot be relied upon to measure the absorption of native food iron in subjects with iron deficiency is not supported by the findings in the present study. In applying the criteria

\footnotetext{
${ }^{2}$ Layrisse, M., and C. Martinez-Torres. Unpublished observations.
}

established in 1968 by a scientific working committee of the WHO (35) to the 158 subjects listed in the appendix, $16.5 \%$ were anemic (hematocrit below $36 \%$ in women and $39 \%$ in men), $22.8 \%$ were iron-deficient based on a serum iron below $50 \mu \mathrm{g} / 100 \mathrm{ml}$ and $25.3 \%$ were iron-deficient as defined by a transferrin saturation below $15 \%$. A total of 112 or $70.9 \%$ of the subjects were normal by all the criteria listed above, although if the level of inorganic iron absorption is taken as a criteria of iron status (36), the mean absorption of $33.1 \%$ in the female population and $38.8 \%$ in the male subjects suggests a high prevalence of iron depletion. In this mixed population of normal and iron-deficient subjects, no correlation was found between the $\mathrm{E}: \mathrm{I}$ ratio and the transferrin saturation $(r=-0.08, P>0.2)$.

The practical application of extrinsic tagging in studies of food iron absorption must take into account our present understanding of the absorptive mechanism of food iron. There is now good evidence that iron is absorbed in two forms: reduced ionized (nonheme) iron and heme iron. While nonheme iron absorption is altered by the addition of either blocking substances such as desferrioxamine or phytate, or enhancing substances such as ascorbic acid or animal muscle, the absorption of heme iron is unaffected. We have obtained evidence in other studies that with extrinsic tagging, heme iron absorption must be considered an independent system. ${ }^{2}$ Total iron absorption from a meal containing both animal and vegetable foods can be measured by determining heme and nonheme iron in the meal by chemical methods, and by employing double extrinsic tags of heme and inorganic iron. However, because heme iron constitutes little, if any of the dietary iron in geographic areas where iron deficiency is most prevalent, and because heme iron absorption appears to be independent of the diet composition, measurement of nonheme iron absorption is perhaps of more immediate concern in studies of food iron availability.

The present finding that absorption of iron added to food closely approaches the absorption of native nonheme food iron has important implications for understanding food iron absorption. The emphasis in absorption studies with isolated test doses of biosynthetically tagged foods has been directed to the biological form of iron within the food. The findings in the present study however, suggest that a common pool of nonheme iron is formed by foods ingested in the same meal, and that the availability of this iron is determined by the composite effect of substances in the meal which either block or facilitate absorption. It would seem appropriate in future studies to clarify the nature of these factors and to define their relative importance in the absorption of dietary iron. 


\section{APPENDIX-TABLES IV AND V}

TABLE IV

Absorption of Food Iron from Test Meals Tagged Simultaneously with Intrinsic and Extrinsic Radioiron

\begin{tabular}{|c|c|c|c|c|c|c|c|c|}
\hline & \multirow[b]{2}{*}{$\begin{array}{l}\text { Sex and } \\
\text { age }\end{array}$} & \multirow[b]{2}{*}{ Hematocrit } & \multirow[b]{2}{*}{$\begin{array}{c}\text { Serum } \\
\text { iron }\end{array}$} & \multirow[b]{2}{*}{$\begin{array}{l}\text { Transferrin } \\
\text { saturation }\end{array}$} & \multicolumn{4}{|c|}{ Iron absorption } \\
\hline & & & & & Intrinsic & Extrinsic & Reference & $\frac{\text { Extrinsic }}{\text { Intrinsic }}$ \\
\hline & & $\%$ & $\mu \mathrm{g} / 100 \mathrm{ml}$ & $\%$ & & & 70 & \\
\hline \multicolumn{9}{|c|}{ Ferric chloride $0.001 \mathrm{mg}$ iron, added to maize after boiling } \\
\hline 1 & F 24 & 36 & 57 & 21 & 0.4 & 0.6 & 17.3 & 1.25 \\
\hline 2 & F 39 & 40 & 80 & 34 & 0.4 & 0.6 & 23.7 & 1.25 \\
\hline 3 & F 48 & 39 & 87 & 27 & 0.7 & 0.8 & 38.0 & 1.17 \\
\hline 4 & F 54 & 41 & 113 & 37 & 1.1 & 1.6 & 16.0 & 1.40 \\
\hline 5 & F 22 & 39 & 48 & 14 & 1.7 & 1.7 & 14.4 & 1.07 \\
\hline 6 & M 25 & 47 & 69 & 18 & 1.6 & 1.8 & 61.6 & 1.14 \\
\hline 7 & F 15 & 44 & 114 & 34 & 4.3 & 4.9 & 27.1 & 1.13 \\
\hline 8 & M 25 & 45 & 107 & 28 & 5.1 & 5.7 & 43.6 & 1.11 \\
\hline 9 & M 32 & 41 & 53 & 17 & 6.1 & 6.0 & 4.8 & 0.98 \\
\hline 10 & M 23 & 41 & 39 & 9 & 7.2 & 7.8 & 41.8 & 1.08 \\
\hline 11 & M 18 & 44 & 69 & 21 & 7.8 & 8.1 & 40.3 & 1.04 \\
\hline 12 & M 15 & 36 & 88 & 21 & 7.9 & 8.9 & 91.1 & 1.13 \\
\hline 13 & M 50 & 32 & 38 & 9 & 18.6 & 20.7 & 75.3 & 1.11 \\
\hline
\end{tabular}

Ferric chloride $0.1 \mathrm{mg}$ iron, added to maize after boiling

$\begin{array}{rlrrrrrrr}1 & \text { F } 27 & 41 & 72 & 27 & 1.7 & 2.1 & 26.8 & 1.27 \\ 2 & \text { M } 48 & 44 & 99 & 29 & 2.0 & 2.1 & 47.8 & 1.06 \\ 3 & \text { F } 33 & 43 & 74 & 18 & 2.0 & 2.8 & 75.7 & 1.39 \\ 4 & \text { M } 37 & 46 & 126 & 37 & 2.1 & 2.2 & 42.3 & 1.05 \\ 5 & \text { F } 26 & 38 & 80 & 29 & 2.4 & 2.3 & 48.2 & 0.95 \\ 6 & \text { F 22 } & 39 & 73 & 23 & 2.6 & 2.8 & 31.7 & 1.09 \\ 7 & \text { M } 15 & 43 & 182 & 53 & 2.7 & 2.2 & 17.8 & 0.83 \\ 8 & \text { M } 45 & 44 & 128 & 36 & 2.9 & 3.2 & 47.8 & 1.12 \\ 9 & \text { F } 34 & 35 & 65 & 17 & 3.7 & 4.0 & 74.6 & 1.09 \\ 10 & \text { F 22 } & 39 & 92 & 32 & 4.4 & 4.3 & 35.8 & 0.98 \\ 11 & \text { M } 35 & 47 & 98 & 30 & 4.7 & 4.4 & 19.2 & 0.95 \\ 12 & \text { F } 21 & 41 & 134 & 41 & 6.8 & 6.4 & 54.6 & 0.95 \\ 13 & \text { F } 39 & 37 & 62 & 25 & 7.0 & 7.3 & 51.8 & 1.05 \\ 14 & \text { M } 18 & 48 & 154 & 49 & 9.1 & 9.2 & 63.8 & 1.01 \\ 15 & \text { M 45 } & 35 & 20 & 6 & 13.9 & 15.3 & 81.7 & 1.10 \\ 16 & \text { M } 18 & 24 & 12 & 3 & 14.4 & 15.4 & 81.0 & 1.07 \\ 17 & \text { F 35 } & 33 & 29 & 6 & 15.1 & 16.0 & 85.9 & 1.06 \\ 18 & \text { M } 18 & 41 & 52 & 14 & 24.4 & 26.0 & 82.1 & 1.06\end{array}$

Ferric chloride $0.5 \mathrm{mg}$ iron, added to maize after boiling

\begin{tabular}{rrrrrrrrr}
1 & F 54 & 46 & 93 & 28 & 1.6 & 1.6 & 19.7 & 1.00 \\
2 & F 46 & 38 & 45 & 14 & 1.9 & 1.7 & 22.3 & 0.88 \\
3 & M 51 & 38 & 25 & 6 & 2.2 & 2.1 & 41.8 & 0.95 \\
4 & M 16 & 44 & 66 & 18 & 2.6 & 2.6 & 98.0 & 1.00 \\
5 & F 47 & 25 & 13 & 3 & 3.8 & 3.8 & 50.2 & 1.00 \\
6 & M 34 & 44 & 37 & 8 & 3.9 & 4.0 & 81.8 & 1.03 \\
7 & F 22 & 41 & 112 & 29 & 4.4 & 4.4 & 46.4 & 1.00 \\
8 & F 25 & 25 & 12 & 2 & 4.4 & 4.3 & 20.0 & 0.98 \\
9 & F 27 & 37 & 26 & 6 & 4.7 & 4.8 & 69.6 & 1.02 \\
10 & M 50 & 46 & 126 & 32 & 5.7 & 6.2 & 64.7 & 1.10 \\
11 & M 16 & 41 & 105 & 30 & 9.1 & 8.3 & 98.2 & 0.91 \\
12 & F 40 & 28 & 13 & 3 & 9.8 & 9.3 & 66.1 & 0.95 \\
\hline
\end{tabular}


TABLE IV-(Continued)

\begin{tabular}{|c|c|c|c|c|c|c|c|c|}
\hline & \multirow{3}{*}{$\begin{array}{l}\text { Sex and } \\
\text { age }\end{array}$} & \multirow[b]{3}{*}{ Hematocrit } & \multirow{3}{*}{$\begin{array}{c}\text { Serum } \\
\text { iron }\end{array}$} & \multirow{3}{*}{$\begin{array}{l}\text { Transferrin } \\
\text { saturation }\end{array}$} & \multicolumn{4}{|c|}{ Iron absorption } \\
\hline & & & & & & & & Extrinsic \\
\hline & & & & & Intrinsic & Extrinsic & Reference & Intrinsic \\
\hline & & $\%$ & $\mu g / 100 m l$ & $\%$ & & & $\%$ & \\
\hline \multicolumn{9}{|c|}{ Ferric chloride $0.001 \mathrm{mg}$ iron, added to maize after boiling } \\
\hline 1 & F 30 & 39 & 107 & 35 & 0.2 & 0.4 & 28.9 & 2.00 \\
\hline 2 & F 63 & 40 & 79 & 23 & 0.4 & 0.6 & 8.7 & 1.25 \\
\hline 3 & F 14 & 39 & 93 & 23 & 0.6 & 0.7 & 31.3 & 1.20 \\
\hline 4 & F 40 & 40 & 54 & 16 & 0.7 & 1.0 & 20.1 & 1.50 \\
\hline 5 & F 57 & 39 & 66 & 22 & 1.8 & 2.0 & 5.3 & 1.13 \\
\hline 6 & F 35 & 40 & 110 & 34 & 1.9 & 1.9 & 22.0 & 1.00 \\
\hline 7 & F 30 & 41 & 126 & 33 & 1.9 & 2.2 & 39.7 & 1.18 \\
\hline 8 & F 19 & 42 & 77 & 24 & 2.3 & 3.8 & 38.3 & 1.62 \\
\hline 9 & F 20 & 40 & 65 & 19 & 2.6 & 2.4 & 46.0 & 0.96 \\
\hline 10 & F 39 & 38 & 89 & 28 & 3.6 & 3.7 & 58.1 & 1.03 \\
\hline 11 & M 14 & 40 & 143 & 40 & 6.8 & 7.2 & 79.4 & 1.07 \\
\hline 12 & F 14 & 43 & 38 & 10 & 10.6 & 12.0 & 89.1 & 1.14 \\
\hline \multicolumn{9}{|c|}{ Ferric chloride $0.1 \mathrm{mg}$ iron, added to maize after boiling } \\
\hline 1 & M 50 & 38 & 45 & 12 & 0.4 & 0.6 & 62.8 & 1.25 \\
\hline 2 & M 50 & 43 & 42 & 14 & 1.0 & 1.0 & - & 1.00 \\
\hline 3 & M 55 & 41 & 118 & 32 & 1.2 & 1.4 & 16.3 & 1.18 \\
\hline 4 & M 23 & 45 & 180 & 52 & 1.7 & 2.0 & 16.2 & 1.20 \\
\hline 5 & F 40 & 36 & 50 & 13 & 2.3 & 2.7 & - & 1.14 \\
\hline 6 & F 24 & 38 & 80 & 20 & 2.8 & 3.4 & 87.9 & 1.24 \\
\hline 7 & F 24 & 40 & 47 & 13 & 4.1 & 4.4 & 63.1 & 1.08 \\
\hline 8 & F 45 & 37 & 70 & 19 & 6.9 & 8.2 & 61.6 & 1.19 \\
\hline 9 & M 16 & 36 & 21 & 4 & 7.1 & 8.4 & 96.6 & 1.19 \\
\hline 10 & F 25 & 41 & 100 & 27 & 7.2 & 8.3 & 68.6 & 1.15 \\
\hline 11 & F 17 & 41 & 141 & 37 & 8.4 & 9.4 & 67.8 & 1.12 \\
\hline 12 & F 48 & 42 & 51 & 13 & 9.7 & 11.1 & 90.7 & 1.15 \\
\hline 13 & M 21 & 48 & 112 & 32 & 10.0 & 10.4 & 39.4 & 1.04 \\
\hline 14 & F 33 & 37 & 68 & 19 & 10.0 & 11.7 & 39.7 & 1.17 \\
\hline 15 & M 25 & 32 & 24 & 6 & 15.8 & 17.3 & 90.0 & 1.10 \\
\hline \multicolumn{9}{|c|}{ Ferric chloride $0.1 \mathrm{mg}$ iron, administered with maize separately } \\
\hline 1 & M 65 & 40 & 76 & 25 & 0.1 & 0.1 & 31.4 & 1.00 \\
\hline 2 & M 35 & 40 & 97 & 32 & 0.4 & 0.6 & 2.9 & 1.25 \\
\hline 3 & M 38 & 45 & 121 & 30 & 1.0 & 1.7 & 8.9 & 1.67 \\
\hline 4 & M 45 & 46 & 104 & 29 & 1.2 & 2.8 & 47.1 & 2.27 \\
\hline 5 & M 24 & 48 & 147 & 53 & 1.7 & 1.7 & 16.0 & 1.00 \\
\hline 6 & M 36 & 49 & 53 & 15 & 3.4 & 7.1 & 8.1 & 2.06 \\
\hline 7 & M 36 & 44 & 103 & 27 & 7.4 & 10.0 & 9.2 & 1.34 \\
\hline 8 & M 16 & 43 & 112 & 35 & 8.4 & 15.9 & 30.9 & 1.88 \\
\hline 9 & M 15 & 38 & 115 & 33 & 11.2 & 22.1 & 80.7 & 1.97 \\
\hline 10 & M 15 & 40 & 97 & 27 & 12.7 & 14.3 & 59.1 & 1.13 \\
\hline 11 & F 36 & 40 & 105 & 39 & 12.9 & 14.3 & 13.0 & 1.11 \\
\hline \multicolumn{9}{|c|}{ Ferric chloride $0.1 \mathrm{mg}$ iron, administered with soybean separately } \\
\hline 1 & M 78 & 44 & 112 & 36 & 0.2 & 0.3 & 22.2 & 1.50 \\
\hline 2 & M 23 & 43 & 98 & 31 & 3.1 & 2.9 & 14.8 & 0.93 \\
\hline 3 & M 17 & 42 & 136 & 42 & 4.2 & 5.3 & 5.0 & 1.26 \\
\hline 4 & M 21 & 42 & 41 & 13 & 5.2 & 7.7 & 85.1 & 1.47 \\
\hline 5 & M 21 & 47 & 145 & 36 & 9.4 & 10.1 & 13.6 & 1.07 \\
\hline 6 & M 22 & 46 & 78 & 19 & 10.1 & 11.4 & 67.0 & 1.13 \\
\hline
\end{tabular}


TABLE IV-(Continued)

\begin{tabular}{|c|c|c|c|c|c|c|c|c|}
\hline & \multirow[b]{2}{*}{$\begin{array}{l}\text { Sex and } \\
\text { age }\end{array}$} & \multirow[b]{2}{*}{ Hematocrit } & \multirow[b]{2}{*}{$\begin{array}{c}\text { Serum } \\
\text { iron }\end{array}$} & \multirow[b]{2}{*}{$\begin{array}{l}\text { Transferrin } \\
\text { saturation }\end{array}$} & \multicolumn{4}{|c|}{ Iron absorption } \\
\hline & & & & & Intrinsic & Extrinsic & Reference & $\frac{\text { Extrinsic }}{\text { Intrinsic }}$ \\
\hline & & $\%$ & $\mu \mathrm{g} / 100 \mathrm{ml}$ & $\%$ & & & $\%$ & \\
\hline \multicolumn{9}{|c|}{ Ferric chloride $0.1 \mathrm{mg}$ iron, administered with soybean separately-(Continued $)$} \\
\hline 7 & F 16 & 41 & 91 & 20 & 10.2 & 14.0 & 111.4 & 1.37 \\
\hline 8 & M 37 & 34 & 31 & 7 & 10.3 & 16.8 & 117.6 & 1.62 \\
\hline 9 & F 60 & 42 & 131 & 38 & 10.4 & 11.1 & 91.0 & 1.06 \\
\hline 10 & M 34 & 38 & 45 & 9 & 17.7 & 19.2 & 93.6 & 1.09 \\
\hline 11 & M 17 & 44 & 57 & 20 & 21.1 & 30.1 & 53.8 & 1.43 \\
\hline
\end{tabular}

Ferric chloride $0.1 \mathrm{mg}$ iron, added to wheat after boiling

$\begin{array}{rrrrrrrrr}1 & \text { F } 23 & 39 & 74 & 24 & 0.8 & 0.8 & 48.2 & 1.00 \\ 2 & \text { F } 43 & 43 & 128 & 35 & 0.9 & 0.9 & 20.2 & 1.00 \\ 3 & \text { F } 45 & 39 & 88 & 30 & 0.9 & 1.4 & 13.1 & 1.63 \\ 4 & \text { F } 55 & 38 & 68 & 22 & 0.9 & 1.4 & 17.1 & 1.63 \\ 5 & \text { F } 50 & 37 & 51 & 19 & 1.2 & 1.2 & 17.2 & 1.00 \\ 6 & \text { F } 22 & 38 & 83 & 21 & 2.2 & 2.4 & 13.8 & 1.10 \\ 7 & \text { F } 20 & 37 & 122 & 39 & 2.3 & 2.2 & 8.6 & 0.95 \\ 8 & \text { F } 28 & 42 & 109 & 34 & 3.2 & 3.3 & 9.4 & 1.03 \\ 9 & \text { F } 34 & 41 & 85 & 26 & 4.0 & 4.0 & 21.6 & 1.00 \\ 10 & \text { F } 60 & 38 & 28 & 7 & 4.8 & 6.2 & 51.9 & 1.30 \\ 11 & \text { M } 60 & 35 & 27 & 7 & 8.2 & 10.7 & 66.7 & 1.30 \\ 12 & \text { F } 40 & 26 & 14 & 3 & 9.3 & 10.7 & 35.9 & 1.14 \\ 13 & \text { F } 56 & 39 & 74 & 20 & 14.3 & 16.8 & 20.3 & 1.17\end{array}$

Ferric chloride $0.1 \mathrm{mg}$ iron, added to black bean after boiling

$\begin{array}{lllllllll}1 & \text { M } 46 & 42 & 108 & 35 & 0.5 & 0.2 & 18.6 & 0.36 \\ 2 & \text { F } 22 & 40 & 112 & 43 & 0.6 & 0.4 & 20.8 & 0.59 \\ 3 & \text { F } 14 & 39 & 98 & 22 & 1.5 & 1.2 & 41.2 & 0.81 \\ 4 & \text { F } 22 & 40 & 78 & 21 & 1.7 & 1.5 & 23.8 & 0.90 \\ 5 & \text { M } 56 & 45 & 51 & 20 & 1.9 & 1.6 & 18.4 & 0.84 \\ 6 & \text { M } 63 & 43 & 131 & 44 & 2.2 & 2.2 & 28.6 & 0.99 \\ 7 & \text { F } 25 & 39 & 44 & 12 & 3.0 & 3.4 & 25.7 & 1.12 \\ 8 & \text { F } 14 & 39 & 84 & 21 & 3.1 & 3.2 & 34.6 & 1.01\end{array}$

Ferric chloride $0.1 \mathrm{mg}$ iron, added after boiling to maize plus $500 \mathrm{mg}$ desferrioxamine

$\begin{array}{rlrrrrrrr}1 & \text { M } 44 & 44 & 88 & 25 & 0.2 & 0.4 & 63.7 & 2.00 \\ 2 & \text { F } 37 & 35 & 138 & 29 & 0.2 & 0.2 & 55.1 & 1.00 \\ 3 & \text { F } 55 & 39 & 106 & 29 & 0.3 & 0.3 & 36.3 & 1.00 \\ 4 & \text { F } 41 & 40 & 75 & 32 & 0.3 & 0.4 & 27.2 & 1.33 \\ 5 & \text { M } 39 & 45 & 69 & 22 & 0.3 & 0.6 & 31.4 & 1.67 \\ 6 & \text { M } 49 & 43 & 78 & 20 & 0.7 & 0.9 & 69.3 & 1.33 \\ 7 & \text { F } 46 & 39 & 118 & 34 & 0.7 & 0.8 & 35.7 & 1.17 \\ 8 & \text { F } 44 & 38 & 56 & 17 & 0.8 & 0.9 & 12.9 & 1.14 \\ 9 & \text { F } 33 & 40 & 65 & 21 & 0.9 & 1.1 & 40.8 & 1.25 \\ 10 & \text { M } 32 & 46 & 63 & 13 & 1.0 & 1.2 & 40.1 & 1.22 \\ 11 & \text { F 38 } & 38 & 69 & 21 & 1.3 & 1.4 & 59.8 & 1.08 \\ 12 & \text { M } 30 & 37 & 19 & 5 & 1.4 & 1.4 & 60.9 & 1.00\end{array}$

Ferric chloride $0.1 \mathrm{mg}$ iron, added after boiling to maize plus $500 \mathrm{mg}$ ascorbic acid

\begin{tabular}{rrrrrrrrr}
1 & F 70 & 40 & 99 & 24 & 3.4 & 3.4 & 8.8 & 1.00 \\
2 & M 55 & 43 & 75 & 30 & 4.1 & 4.3 & 10.5 & 1.06 \\
3 & F 40 & 38 & 44 & 13 & 8.5 & 9.0 & 31.4 & 1.05 \\
4 & F 53 & 44 & 48 & 13 & 15.6 & 16.6 & 20.1 & 1.06 \\
\hline
\end{tabular}


TABLE IV-(Continued)

\begin{tabular}{|c|c|c|c|c|c|c|c|c|}
\hline & \multirow[b]{2}{*}{$\begin{array}{l}\text { Sex and } \\
\text { age }\end{array}$} & \multirow[b]{2}{*}{ Hematocrit } & \multirow[b]{2}{*}{$\begin{array}{c}\text { Serum } \\
\text { iron }\end{array}$} & \multirow[b]{2}{*}{$\begin{array}{l}\text { Transferrin } \\
\text { saturation }\end{array}$} & \multicolumn{4}{|c|}{ Iron absorption } \\
\hline & & & & & Intrinsic & Extrinsic & Reference & $\frac{\text { Extrinsic }}{\text { Intrinsic }}$ \\
\hline & & $\%$ & $\mu g / 100 m l$ & $\%$ & \multicolumn{4}{|c|}{$\%$} \\
\hline \multicolumn{9}{|c|}{ Ferric chloride $0.1 \mathrm{mg}$ iron, added after boiling to maize plus $500 \mathrm{mg}$ ascorbic acid-(Continued) } \\
\hline 5 & M 52 & 40 & 150 & 44 & 17.7 & 18.3 & 69.0 & 1.04 \\
\hline 6 & M 51 & 38 & 163. & 54 & 19.3 & 19.1 & 20.6 & 0.99 \\
\hline 7 & M 33 & 48 & 91 & 24 & 20.4 & 20.2 & 34.6 & 0.99 \\
\hline 8 & M 40 & 42 & 83 & 25 & 21.7 & 21.9 & 49.3 & 1.01 \\
\hline 9 & F 40 & 39 & 65 & 17 & 32.2 & 33.8 & 61.4 & 1.05 \\
\hline 10 & M 45 & 38 & 38 & 9 & 48.6 & 49.7 & 72.3 & 1.02 \\
\hline 11 & F 33 & 26 & 14 & 2 & 49.3 & 52.2 & 69.0 & 1.06 \\
\hline 12 & M 17 & 41 & 104 & 35 & 52.9 & 52.3 & 69.0 & 0.99 \\
\hline 13 & M 23 & 37 & 18 & 4 & 67.7 & 69.7 & 34.8 & 1.03 \\
\hline 14 & M 17 & 42 & 73 & 18 & 78.3 & 77.0 & 70.9 & 0.98 \\
\hline \multicolumn{9}{|c|}{ Ferric chloride $0.1 \mathrm{mg}$ iron, added to maize after boiling and administered with veal } \\
\hline 1 & M 56 & 41 & 57 & 17 & 2.8 & 4.0 & 36.8 & 1.43 \\
\hline 2 & F 52 & 37 & 55 & 19 & 4.4 & 5.5 & 36.6 & 1.25 \\
\hline 3 & F 40 & 38 & 33 & 9 & 7.2 & 8.3 & 38.0 & 1.15 \\
\hline 4 & M 52 & 43 & 98 & 29 & 11.2 & 12.9 & 78.4 & 1.15 \\
\hline 5 & F 15 & 40 & 74 & 17 & 13.9 & 16.4 & 22.9 & 1.18 \\
\hline 6 & M 38 & 46 & 122 & 38 & 16.0 & 17.9 & 71.9 & 1.12 \\
\hline 7 & F 58 & 36 & 43 & 13 & 16.7 & 19.6 & 61.8 & 1.17 \\
\hline 8 & F 48 & 28 & 15 & 4 & 21.1 & 24.2 & 58.0 & 1.15 \\
\hline
\end{tabular}

TABLE V

Absorption of Maize Labeled with Intrinsic and Extrinsic Radioiron and Administered with a Complete Meal

\begin{tabular}{|c|c|c|c|c|c|c|c|c|}
\hline & \multirow[b]{3}{*}{$\begin{array}{l}\text { Sex and } \\
\text { age }\end{array}$} & \multirow[b]{3}{*}{$\begin{array}{l}\text { Packed } R B C \\
\text { volume }\end{array}$} & \multirow[b]{3}{*}{$\begin{array}{c}\text { Serum } \\
\text { iron }\end{array}$} & \multirow[b]{3}{*}{$\begin{array}{l}\text { Transferrin } \\
\text { saturation }\end{array}$} & \multicolumn{4}{|c|}{ Iron absorption } \\
\hline & & & & & \multicolumn{2}{|c|}{ Normal meal } & \multicolumn{2}{|c|}{ Homogenized meal } \\
\hline & & & & & Intrinsic & Extrinsic & Intrinsic & Extrinsic \\
\hline & & $\%$ & $\mu \mathrm{g} / 100 \mathrm{ml}$ & $\%$ & \multicolumn{4}{|c|}{$\%$} \\
\hline 1 & F 18 & 39 & 145 & 45 & 2.7 & 3.7 & 4.4 & 6.1 \\
\hline 2 & F 19 & 40 & 151 & 52 & 2.8 & 3.7 & 5.2 & 6.2 \\
\hline 3 & F 21 & 42 & 121 & 28 & 2.8 & 3.3 & 1.2 & 1.3 \\
\hline 4 & F 23 & 42 & 130 & 47 & 3.5 & 4.3 & 3.5 & 4.3 \\
\hline 5 & F 23 & 41 & 116 & 34 & 3.5 & 4.8 & 0.9 & 1.0 \\
\hline 6 & F 34 & 46 & 109 & 34 & 5.2 & 6.3 & 3.4 & 4.3 \\
\hline 7 & F 18 & 34 & 52 & 19 & 8.0 & 9.8 & 2.5 & 2.4 \\
\hline 8 & F 18 & 41 & 116 & 34 & 9.7 & 14.0 & 4.5 & 5.0 \\
\hline 9 & F 20 & 46 & 199 & 39 & 11.3 & 15.6 & 2.4 & 2.7 \\
\hline 10 & F 18 & 41 & 116 & 29 & 13.8 & 17.7 & 8.9 & 9.7 \\
\hline 11 & F 25 & 40 & 32 & 10 & 32.0 & 40.2 & 38.0 & 39.9 \\
\hline
\end{tabular}

\section{ACKNOWLEDGMENTS}

It is a pleasure to acknowledge the help and suggestions of Dr. Eloise Giblett in preparation of this manuscript for publication.

This investigation was supported by U. S. Public Health Service grants HE-06242, AM-13067, HE-06508, and (Train- ing Grant) AM-5130, by Department of Agriculture Grant 12-14-100-9918 (61), by the Williams-Waterman Research Corporation, and by the World Health Organization. A portion of this work was conducted through the Clinical Research Center facility of the University of Washington supported by NIH grant FR-37.

814 Cook, Layrisse, Martinez-Torres, Walker, Monsen, and Finch 


\section{REFERENCES}

1. Moore, C. V., and R. Dubach. 1951. Observations on the absorption of iron from foods tagged with radioiron. Trans. Ass. Amer. Physicians Philadelphia. 64: 245.

2. Chodos, R. B., J. F. Ross, L. Apt, M. Pollycove, and J. A. E. Halkett. 1957. The absorption of radioiron labeled foods and iron salts in normal and iron deficient subjects and in idiopathic hemochromatosis. $J$. Clin. Invest. 36: 314.

3. Halkett, J. A. E., R. B. Chodos, and J. F. Ross. 1959. The labeling of human foods with radioactive iron $\left(\mathrm{Fe}^{6 \theta}\right)$. J. Lab. Clin. Med. 53: 816.

4. Schulz, J., and N. J. Smith. 1958. A quantitative study of the absorption of food iron in infants and children. Amer. J. Dis. Child. 95: 109.

5. Hussain, R., R. B. Walker, M. Layrisse, P. Clark, and C. A. Finch. 1965. Nutritive value of food iron. Amer. J. Clin. Nutr. 16: 464.

6. Kuhn, I. N., M. Layrisse, M. Roche, C. Martinez, and R. B. Walker. 1968. Observations on the mechanism of iron absorption. Amer. J. Clin. Nutr. 21: 1184.

7. Layrisse, M., C. Martinez-Torres, and M. Roche. 1968. The effect of interaction of various foods on iron absorption. Amer. J. Clin. Nutr. 21: 1175.

8. Callender, S. T., and G. T. Warner. 1968. Iron absorption from bread. Amer. J. Clin. Nutr. 21: 1170.

9. Elwood, P. C., D. Newton, J. D. Eakins, and D. A. Brown. 1968. Absorption of iron from bread. Amer. J. Clin. Nutr. 21: 1162.

10. Layrisse, M., J. D. Cook, C. Martinez, M. Roche, I. N. Kuhn, R. B. Walker, and C. A. Finch. 1969. Food iron absorption: a comparison of vegetable and animal foods. Blood. 33: 430.

11. Elwood, P. C., I. T. Benjamin, F. A. Fry, J. D. Eakins, D. A. Brown, P. C. De Kock, and J. U. Shah. 1970. Absorption of iron from chipatti made from wheat flour. Amer. J. Clin. Nutr. 23: 1267.

12. Martinez-Torres, C., and M. Layrisse. 1970. Effect of amino acids on iron absorption from a staple vegetable food. Blood. 35: 669.

13. Callender, S. T., S. R. Marney, Jr., and G. T. Warner. 1970. Eggs and iron absorption. Brit. J. Haematol. 19: 657.

14. The International Committee for Standardization in Hematology. 1971. Proposed recommendations for measurement of serum iron in human blood. Blood. 37: 598 .

15. Herbert, V., C. W. Gottlieb, K.-S. Lau, M. Fisher, N. R. Gevirtz, and L. R. Wasserman. 1966. Coated charcoal assay of unsaturated iron-binding capacity. J. Lab. Clin. Med. 67: 855.

16. Ramsay, W. N. M. 1957. The determination of the total iron-binding capacity of serum. Clin. Chim. Acta. 2: 221.

17. Retzlaff, J. A., W. N. Tauxe, J. M. Kiely, and C. F. Stroebel. 1969. Erythrocytic volume, plasma volume, and lean body mass in adult men and women. Blood. 33: 649.

18. Eakins, J. D., and D. A. Brown. 1966. An approved method for the simultaneous determination of iron-55 and iron-59 in blood by liquid scintillation counting. Int. J. Appl. Radiat. Isotop. 17: 391.

19. Dern, R. J., and W. L. Hart. 1961. Studies with doubly labeled iron. I. Simultaneous liquid scintillation counting of isotopes $\mathrm{Fe}^{5 \mathrm{~s}}$ and $\mathrm{Fe}^{5 \mathrm{~s}}$ as ferrous perchlorate. J. Lab. Clin. Med. 57: 322.

20. Dern, R. J., and W. L. Hart. 1961. Studies with doubly labeled iron. II. Separation of iron from blood samples and preparation of ferrous perchlorate for liquid scintillation counting. J. Lab. Clin. Med. 57: 460.

21. Palmer, H. E., and J. D. Cook. 1971. A counter for the direct measurement of ${ }^{55} \mathrm{Fe}$ in blood and other liquid samples. I.E.E.E. Trans. Nucl. Sci. 18: 68.

22. Watt, B. K., and A. L. Merrill. 1963. Department of Agriculture, Washington, D. C. Composition of foods. Agricultural Handbook No. 8.

23. Snedecor, G. W., and W. G. Cochran. 1967. In Statistical Methods. Iowa State University Press, Ames. 6th edition. 166, 296.

24. Steel, R. G. D., and J. H. Torrie. 1960. In Principles and Procedures of Statistics, with Special Reference to the Biological Sciences. McGraw-Hill Book Company, New York. 319.

25. Green, R., R. Charlton, H. Seftel, T. Bothwell, F. Mayet, B. Adams, C. Finch, and M. Layrisse. 1968. Body iron excretion in man. A collaborative study. Amer. J. Med. 45: 336.

26. Sharpe, L. M., W. C. Peacock, R. Cooke, and R. S. Harris. 1950. The effect of phytate and other food factors on iron absorption. J. Nutr. 41: 433.

27. Pirzio-Biroli, G., T. H. Bothwell, and C. A. Finch. 1958. Iron absorption. II. The absorption of radioiron administered in a standard meal in man. J. Lab. Clin. Med. 51: 37 .

28. Stevens, A. R., Jr., G. Pirzio-Biroli, H. N. Harkins, L. M. Nyhus, and C. A. Finch. 1959. Iron metabolism in patients after partial gastrectomy. Ann. Surg. 149: 534.

29. Davis, A. E., and J. Badenoch. 1962. Iron absorption in pancreatic disease. Lancet. $2: 6$.

30. Goldberg, A., A. C. Lochhead, and J. H. Dagg. 1963. Histamine-fast achlorhydria and iron absorption. Lancet. 1: 848.

31. Cook, J. D., G. M. Brown, and L. S. Valberg. 1964. The effect of achylia gastrica on iron absorption. $J$. Clin. Invest. 43: 1185 .

32. Jacobs, A., and G. M. Owen. 1969. Effect of gastric juice on iron absorption in patients with gastric atrophy. Gut. 10: 488.

33. Jacobs, A. M., and G. M. Owen. 1969. The effect of age on iron absorption. J. Gerontol. 24: 95.

34. Moore, C. V. 1968. Absorption of iron from foods. In Occurrence, Causes and Prevention of Nutritional Anaemias (Symposia of the Swedish Nutrition Foundation VI, Tylosand, Sweden, August, 1967). G. Blix, editor. Uppsala, Almqvist \& Wiksell, Stockholm. 92-102.

35. Report of a WHO Scientific Group. 1968. Nutritional Anaemias. World Health Organization, Geneva. WHO Technical Report Series No. 405.

36. Kuhn, I. N., E. R. Monsen, J. D. Cook, and C. A. Finch. 1968. Iron absorption in man. J. Lab. Clin. Med. 71: 715 . 